\title{
O DESIGN COMO FERRAMENTA DE VALORIZAÇÃO DO TERRITÓRIO: APLICAÇÃO DA METODOLOGIA DE DESIGN E TERRITÓRIO EM UMA EMBALAGEM DE SAL MARINHO
}

\author{
Fernando de Oliveira Linhares \\ Universidade Federal de Campina Grande \\ Fernandoolinhares@yahoo.com.br \\ Cleone Ferreira de Souza, Msc. \\ Universidade Federal de Campina Grande \\ cleone@ddi.ufcg.edu.br
}

Resumo: Este trabalho tem como objetivo relatar a valorização do território por intermédio do design. Assim, foi utilizada a metodologia apresentada por Lia Kruchen, em Design e Território, que utiliza o design como ferramenta de valorização de um produto, estudando o contexto local, com o objetivo de potencializar as competências existentes no território, transformando-as em qualidades, traduzidas e transcritas para um produto físico. Sendo assim, para aplicação da metodologia, foi escolhida a cidade de Mossoró, município brasileiro, localizado no interior do Rio Grande do Norte. Inicialmente, foi feito um levantamento histórico e cultural do município, que é bastante famoso por ser uma cidade quente. Além disso, é uma cidade rica culturalmente, fundada por fazendeiros e nomeada de Mossoró, inspirada na tribo indígena Monxoró, que habitava a região. As principais atividades econômicas são a exploração de sal marinho, segundo maior produtor do País, e a exploração de petróleo. A cidade revive os acontecimentos históricos sazonalmente por meio de peças teatrais, exposição em museus e festas típicas. A partir do levantamento do contexto histórico e cultural da cidade, o produto escolhido para o trabalho de valorização do território foi o sal marinho, que é transportado para vários estados do País. Foi identificado nas embalagens que não existe comunicação quanto a sua origem, o que poderia agregar valor ao produto e ao território, por meio da informação gráfica contida na embalagem. Assim, os consumidores poderiam ter conhecimento da sua história e cultura tão ricas, como o fato de Mossoró ter libertado os escravos cinco anos antes da Lei Áurea e o motim das mulheres, registrado como a primeira rebelião feminina pelo direito ao voto no Brasil, difundindo para os consumidores de outros estados a procedência do sal que eles consomem, vinculando ainda à uma história de riqueza cultural, através de fatos históricos que têm a ver não só com a história local, mas também com a própria história do Brasil. Com intuito de valorizar o contexto, cultura e história local, foi desenvolvida uma nova marca e embalagem para o sal marinho, denominada de "Monxoró", numa alusão a tribo indígena que povoava a região. No verso da embalagem, a história da cidade é contada através dos principais fatos. Também foi 
idealizado a criação de um site da marca com informações mais completas em que estaria indicado onde o consumidor poderia encontrar mais informações e conhecer a localização geográfica, bem como os principais pontos a serem visitados em Mossoró. $O$ design tem um papel importante na agregação de valor a um produto. Fazendo uso de valores materiais, culturais e da história de contextos locais como ferramenta para impregnar de significados a relação usuário/produto, essa metodologia possibilita o reconhecimento do produto através dos atributos e qualidades de um território. Ela ainda colabora com a proteção do certificado de origem de um produto relacionado ao seu território, promovendo e desenvolvendo novos artefatos ou otimizando os já existentes, contribuindo para consolidar um produto no mercado para além de seus valores comerciais, mas também os seus valores simbólicos e culturais.

Palavras-chave: Design e Território, Metodologias do Design, Sal Marinho, Mossoró 